\title{
Performance Testing of a Family of Type I Combination Appliances
}

Stanley T. Liu

George E. Kelly

Charles P. Terlizzi

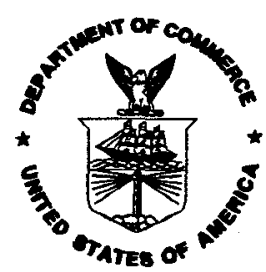

U.S. Department of Commerce Ronald H. Brown, Secretary Mary L. Good, Under Secretary for Technology National Institute of Standards and Technology Arati Prabhakar, Director

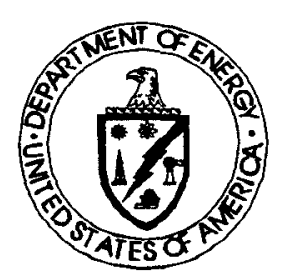

Prepared for:

U.S. Department of Energy Office of Codes \& Standards 1000 Independence Ave., SW Washington, DC 20585 


\begin{abstract}
ANSI/ASHRAE Standard 124-1991 specifies the laboratory test and the calculation procedures for estimating seasonal and annual performance of combination appliances which are designed to provide both space heating and water heating. A boiler that includes a tankless coil for water heating or in combination with an indirectly heated storage tank is classified by ASHRAE standard 124 as Type I combination appliances. It is common for a single size tankless coil or storage tank to be used in combination with a series of boilers (called a family series) of different sizes. In an effort to minimize the test burdens on manufacturers, a family series of gas-fired hot water boilers were tested to determine if a subset of a family series of Type I combination appliances could be tested and used to predict the performance of the rest of the appliances in the family series. Tests were conducted on a family series of three different size boilers (rated input of 22,33 , and $44 \mathrm{~kW}$ ) with an identical indirectly heated storage tank to determine their Combined Annual Efficiency (CAE) as specified in ASHRAE standard 124. To this end, tests for the Energy Factor (EF) for water heating and the Annual Fuel Utilization Efficiency (AFUE) for space heating were conducted. For the domestic water heating test, daily hot water draw volume of $243.4 \mathrm{I}(64.3 \mathrm{gal})$ was used. The results showed that for the three boilers, the AFUE for space heating differed by approximately 2.5 percentage points, with the smaller size boiler having a higher AFUE. On the other hand, the EF for water heating depended more strongly (differed by near 5 percentage points from the smallest $(22 \mathrm{~kW})$ to the largest $(44 \mathrm{~kW})$ capacity boilers tested) on the size of the boilers for the same daily hot water drawn. However, the EF was an approximate linear function of the boiler size. The results also showed that the CAE varied by slightly over 1.6 percentage points among the three boilers. Thus a simple linear interpolation appears adequate for determining the Combined Annual Efficiency CAE within a family series.
\end{abstract}

Key words: Annual Fuel Utilization Efficiency, ANSI/ASHRAE Std.103, ASHRAE Std. 124, boiler, building technology, combination appliance, combined annual efficiency, DOE test procedure, domestic water storage tank, energy factor, heating seasonal efficiency, integrated appliance, linear interpolation, rating, space heating, steady-state efficiency, water heating 


\section{ACKNOWLEDGEMENTS}

This study was sponsored by the U.S. Department of Energy, Office of Energy Efficiency and Renewable Energy, Office of Codes and Standards. The authors would also like to express their appreciation to Mr. John I. Woodworth, Secretary of the ASHRAE standard Project Committee 124P, for his valuable advice and assistance in the selection and obtaining of the test boiler and storage tank units. 


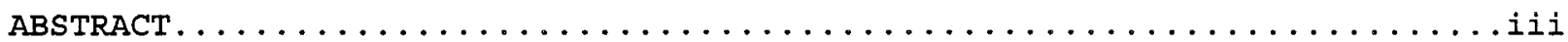

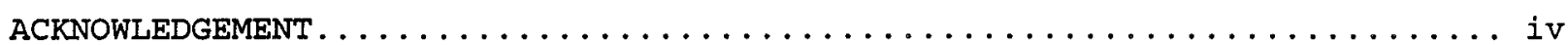

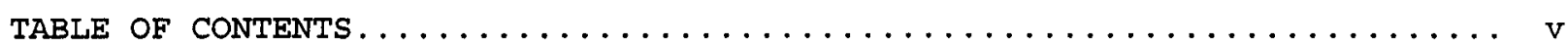

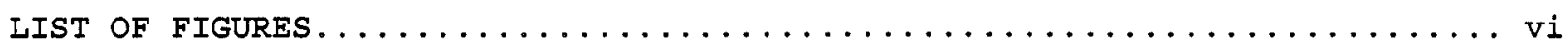

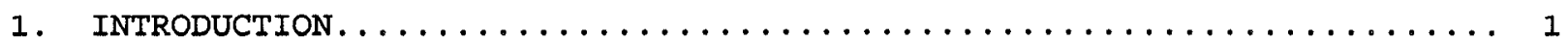

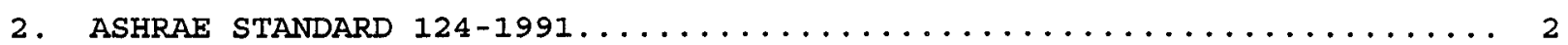

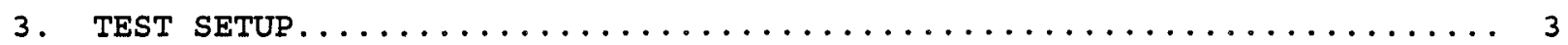

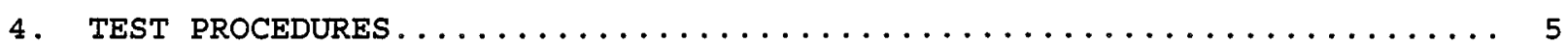

4.1 Space Heating - steady-state Test and Cyclic Operation (Cool-

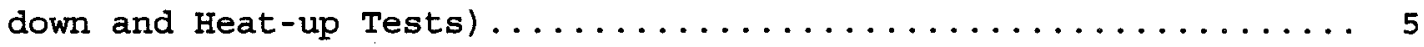

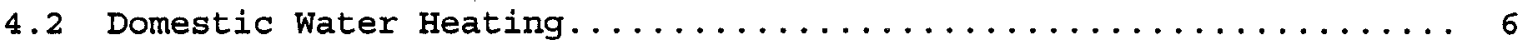

4.2 .1 Setting storage Tank Thermostat................. 6

4.2 .2 Simulated Hot Water Use Test...................... 7

4.2 .3 First-Hour Rating Test...................... 7

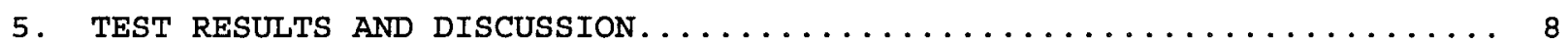

5.1 steady-state and Cyclic (Cool-down and Heat-up) Tests......... 8

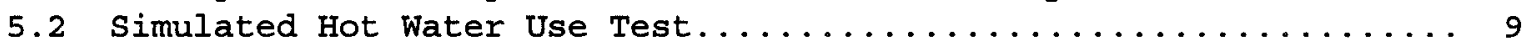

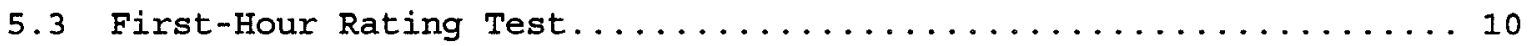

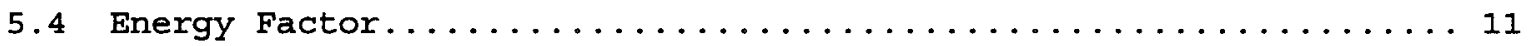

5.5 Space Heating Efficiency and Combined Annual Efficiency....... 12

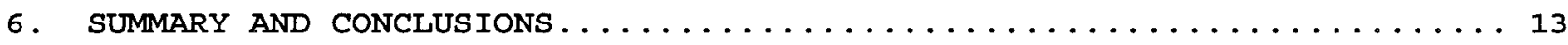

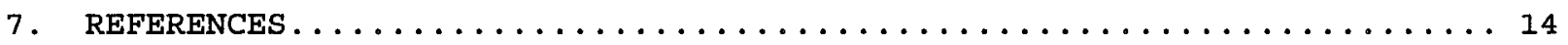

APPENDIX A Calculation of Combined Annual Efficiency (CAE) by the ANSI/ASHRAE Standard 124-1991 Procedure............... 15

APPENDIX B Measurement Uncertainty........................ 
Fig. 1 Schematic of a boiler with domestic water storage tank....... 17

Fig. 2 Flue gas, boiler outlet and domestic water outlet temperature under the 24-hour simulated use test condition (over the first

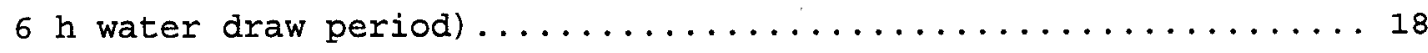

Fig. 3 Flue gas, boiler outlet and domestic water outlet temperature under the 24-hour simulated use test condition (over the $24 \mathrm{~h}$

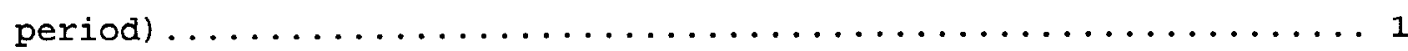

Fig. 4. On and off status of the domestic water outlet valve, fuel gas valve and boiler water circulation pump during the 24-hour

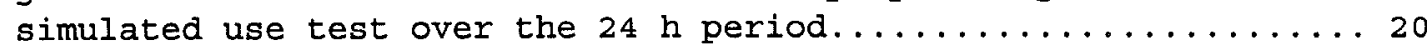

Fig. 5 Flue gas, tank mean water and domestic water outlet temperature during the first-hour rating test $(33 \mathrm{kw}$ input) ............ 21

Fig. 6 Flue gas, tank mean water and domestic water outlet temperature during the first-hour rating test $(22 \mathrm{~kW}$ input $) \ldots \ldots \ldots \ldots \ldots .22$

Fig. 7 Flue gas, tank mean water and domestic water outlet temperature during the first-hour rating test $(44 \mathrm{~kW}$ input) $\ldots \ldots \ldots \ldots \ldots 23$

Fig. 8 First-hour rating as a function of rated input of a family series of boilers with identical storage tank............ 24

Fig. 9 Energy Factor, steady-state efficiency, heating seasonal efficiency and Combined Annual Efficiency (CAE) as a function of rated input of a family series of boilers with

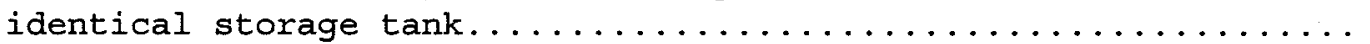




\section{INTRODUCTION}

During the past several years, combination appliances that integrate the functions of space heating and domestic hot water heating into a single system have received renewed interest. A test method and calculation procedure for estimating and rating the seasonal and annual performance of such combination appliances was published by the American Society of Heating, Refrigerating and Air-Conditioning Engineers, Inc. (ASHRAE) in 1991 as ANSI/ASHRAE Standard 1241991, "Method of Testing for Rating Combination Space Heating/Water Heating Appliances" [1]. In this new standard (abbreviated in this report as ASHRAE standard 124), combination appliances are classified into two types, Type I and Type II. Type I appliances are those whose primary function is space heating with domestic water heating as the secondary function. Type II appliances have domestic water heating as their primary function and space heating as their secondary function.

In ASHRAE Standard 124, Type I combination appliances are subdivided into two types; one is a boiler with a tankless coil in the boiler for domestic water heating, and the other is a boiler in combination with an indirectly heated domestic water storage tank. The latter is called Type I integrated appliance and is defined as a combined boiler/domestic water storage tank system where the tank water is indirectly heated by the hot water from the boiler through an immersed hot water coil in the tank. ASHRAE Standard 124 specifies that Type I appliances shall be tested as a boiler in accordance with the ANSI/ASHRAE Standard 103 [2], and as a water heater in accordance with a procedure similar to the DOE test procedure for water heaters [3]. ASHRAE Standard 124 does not, however, address the problem that different size boilers are usually combined with a single sized tankless coil or domestic storage tank. If all combinations of boilers and tankless coil or storage tank had to be tested, a significant testing burden would be placed on boiler manufacturers. At the present time, most "family series (boilers with similar configuration in construction)" of boilers incorporate only one or two different size tankless coil or storage tanks. If only two different size boilers in a family series with an identical tankless coil or storage tank could be tested and the results used to predict the performance of other size boilers in the same family series by an interpolating scheme, a significant amount of testing could be avoided.

In 1988-1989, through the sponsorship of the Department of Energy (DOE), NIST developed a computer model and conducted laboratory tests on a clam-shell, wetbase, oil-fired, residential boiler with a tankless domestic water heating coil [4]. The model was verified with laboratory test data for heat-up, cool-down, cyclic, and standby modes of operation along with domestic hot water draw cycles. In 1992, a series of computer simulations were run with the model to predict the annual fuel utilization efficiency (AFUE) for space heating, the energy factor $(E F)$ for water heating, and the combined annual efficiency (CAE) for combined space/water heating functions as prescribed in ASHRAE Standard 124 for a family series of five different size boilers with an identical tankless coil for water heating [5]. The results showed that for a family series of Type I combination boiler/tankless heater appliances, the annual fuel utilization efficiency (AFUE), energy factor (EF) and combined annual efficiency (CAE) all vary linearly as a function of the boiler rated input capacity. That is, all three rating descriptors can be linearly interpolated as a function of the boilers' input capacity. 
The objective of the present study described in this report is to determine the feasibility of the linear interpolating scheme for the other Type I combination appliances (integrated boiler/storage tank). A family series of three gas-fired boilers with input capacity of 22,33 and $44 \mathrm{~kW}(75000,112500$ and $150000 \mathrm{Btu} / \mathrm{h})$, each in combination with a $151.4 \mathrm{~L}$ (40 gal) tank with an immersed $36.6 \mathrm{~kW}$ ( 125000 $\mathrm{Btu} / \mathrm{h}$ ) capacity hot water coil, were tested in accordance with the test procedure specified in ASHRAE Standard 124. For each boiler/storage tank combination, the annual fuel utilization efficiency, energy factor and the combined annual efficiency were calculated. The results from the three boiler/storage tank combinations were used to determine the applicability of the interpolating scheme.

\section{ASHRAE STANDARD 124-1991}

To rate a combination appliance, ASHRAE standard 124 requires individual performance testing of the appliance as a space heating equipment and as a water heater. It does not require a combined space heating and water heating test. The space heating performance of the appliance is determined from tests in accordance with ANSI/ASHRAE 103-1988 (revised in 1993 as ANSI/ASHRAE standard 103-1993), "Methods of Testing for Annual Fuel Utilization Efficiency of Central Furnaces and Boilers" [2]. The domestic water heating performance is determined from tests in accordance with or similar to DOE 10 CFR Part 430 , subpart B, Appendix E, Uniform Test Method for Measuring the Energy Consumption of Water Heaters [3] . The steady-state efficiency, $\mathrm{EFF}_{\mathrm{ss}}$, and space heating seasonal efficiency, $\mathrm{EFF}_{\mathrm{hs}}$, (defined as the space heating part-load efficiency at $22.5 \frac{1}{1} 10 a d$, and is equal to the Annual Fuel Utilization Efficiency, AFUE, for boiler without a continuous pilot) from the space heating performance test and the energy factor from the water heating test are used to calculate the combined annual efficiency (CAE) rating descriptor.

The space heating test of ANSI/ASHRAE 103-1993 for hot water boilers requires a steady-state test lasting a minimum of $30 \mathrm{~min}$, followed by a $45 \mathrm{~min}$ cool-down test and a $9.68 \mathrm{~min}$ heat-up test. The burner on/off is controlled manually for the space heating test. The boiler inlet temperature is specified to be from 48.9 to $51.1{ }^{\circ} \mathrm{C}\left(120\right.$ to $\left.124^{\circ} \mathrm{F}\right)$ and the temperature rise across the boiler is specified to be within 10.56 to $13.33^{\circ} \mathrm{C}$ ( 19 to $24{ }^{\circ} \mathrm{F}$ ).

The domestic water heating test in DOE $10 \mathrm{CFR}$ Part 430 requires that a total of $243.4 \mathrm{~L}(64.3 \mathrm{gal})$ of hot water shall be withdrawn by imposing six equal draws. These draws, which occur at a flow rate of $0.19 \mathrm{~L} / \mathrm{s}(3 \mathrm{Gpm})$ are imposed at the beginning of consecutive hours. The initiation of the first draw designates the beginning of the 24-hour simulated use test. Because the final draw is initiated at an elapsed time of $5 \mathrm{~h}$ and the actual draw is completed within $4 \mathrm{~min}$, the appliance operates in a standby mode for the more than $18 \mathrm{~h}$ that remain before the test is terminated.

During the domestic water heating test, the thermostat in the storage tank controls the on and off states of the gas burner and the water pump. The pump circulates the hot boiler water through the immersed water coil in the storage tank. The burner and the boiler water circulation pump are turned on together 
when the storage water temperature at the tank thermostat decreased below the thermostat cut-in setting, which was factory fixed at $5.55^{\circ} \mathrm{C}\left(10^{\circ} \mathrm{F}\right)$ below the thermostat cut-out setting for the storage tank used in this study. The burner and the water circulation pump are turned off when the tank water temperature reaches the storage tank thermostat cut-out setting of $57.22 \pm 2.78{ }^{\circ} \mathrm{C}(135 \pm 5$ ${ }^{\circ}$ F). In addition, the burner is set to turn off when the boiler outlet water temperature reaches the boiler high limit control setting. However, the circulation pump will continue to run if the water temperature at the tank thermostat has not reached its cut-off setting. The burner is set to turn on when the boiler water temperature drops to below the temperature differential of the boiler if the water circulation pump is in operation. (In this study, the temperature differential of the test boilers was factory set at a fixed $11.1^{\circ} \mathrm{C}$ $\left(20^{\circ} \mathrm{F}\right)$ below the boiler water high limit control setting.) For the domestic water heating tests in this study, the boiler water high limit control was set at $82.2 \pm 1.1{ }^{\circ} \mathrm{C}\left(180 \pm 2{ }^{\circ} \mathrm{F}\right)$, which was $25^{\circ} \mathrm{C}\left(45^{\circ} \mathrm{F}\right)$ above the tank thermostat cut-off.

It is noted that in ASHRAE Standard 124, there is no specific setting for the boiler water high limit control for the Type I integrated appliances except that it should be less than $98.9^{\circ} \mathrm{C}\left(210^{\circ} \mathrm{F}\right)$. The recommended high limit setting by the manufacturer of the test boilers was 82.2 to $93.3{ }^{\circ} \mathrm{C}$ ( 180 to $200{ }^{\circ} \mathrm{F}$ ) for space heating purpose, and the recommended setting by the storage tank manufacturer was that it should be set at a minimum of $11.1{ }^{\circ} \mathrm{C}\left(20{ }^{\circ} \mathrm{F}\right)$ above the setting for the storage tank water temperature. The $82.2{ }^{\circ} \mathrm{C}\left(180^{\circ} \mathrm{F}\right)$ setting was chosen for this study since the setting met the recommendation of the boiler and storage tank manufacturers. In addition, it agreed with the setting specified in ASHRAE Standard 124 for the Type I combination appliance of boilers with a tankless heater for domestic water heating.

In ASHRAE Standard 124, a total hot water draw of either $243.4 \mathrm{~L}$ (64.3 gal) or $454.2 \mathrm{~L}(120 \mathrm{gal})$ is specified. The total volume used depends on the first-hour rating [1] of the boiler. The total draw is $243.4 \mathrm{~L}(64.3 \mathrm{gal})$ if the first-hour

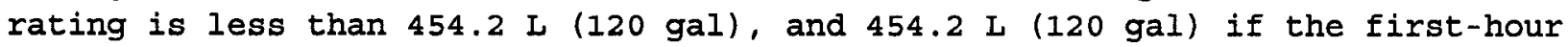
rating is greater than $454.2 \mathrm{~L}$ (120 gal). In the present series of tests, only the $243.4 \mathrm{I}(64.3 \mathrm{gal})$ daily hot water draw volume is used since this is the daily draw volume specified in the DOE hot water heater test procedure regardless of the value of the first-hour rating.

\section{TEST SET-UP}

The Type I integrated appliances used for the tests were a combination of a commercially available gas-fired, induced draft hot water boiler connected to a indirectly heated domestic water storage tank with an immersed hot water coil located near the bottom of the tank. Circulating hot water from the boiler enters and exits the hot water coil through two ports near the bottom of the tank. Cold domestic water from an auxiliary water pre-conditioning tank at the specified temperature enters the storage tank near the bottom (below the water coil) and exits near the top of the tank. The storage tank has a nominal storage capacity of $151.4 \mathrm{~L}(40 \mathrm{gal})$. The family series of boilers have nameplate input capacity of 22,33 and $44 \mathrm{~kW}(75000,112500$ and $150000 \mathrm{Btu} / \mathrm{h})$ and output capacity of $18.24,27.36$ and $36.05 \mathrm{~kW}(62250,93375$ and $123000 \mathrm{Btu} / \mathrm{h})$, respectively. The 
storage tank has a rated heat transfer capacity of $38.3 \mathrm{~kW}(130700 \mathrm{Btu} / \mathrm{h})$ with a tank inlet temperature of $10^{\circ} \mathrm{C}\left(50^{\circ} \mathrm{F}\right)$ and outlet temperature of $60{ }^{\circ} \mathrm{C}$ (140 $\left.{ }^{\circ} \mathrm{F}\right)$, and a constant boiler water temperature of $82.2{ }^{\circ} \mathrm{C}\left(180{ }^{\circ} \mathrm{F}\right)$ with a pump water flow rate of $0.383 \mathrm{~L} / \mathrm{s}(6 \mathrm{Gpm})$ through the heating coil. The boilers employ an intermittent pilot module with interrupted spark ignition of the pilot.

For the space heating tests, the piping arrangement similar to the one recommended in Fig. 6 of ASHRAE standard 103-1993 is used. Specifically, the boiler outlet water at 60 to $62.2{ }^{\circ} \mathrm{C}\left(140\right.$ to $144{ }^{\circ} \mathrm{F}$ ) is mixed with the cold water from the city main before entering into an auxiliary water conditioning tank. The amount of the cold water for mixing is manually controlled by a drain valve downstream of the flow mixing location. The auxiliary water conditioning tank contains an electric heating element and a chilled water loop, which act through a controller to keep the tank water at the required boiler return water temperature of approximately $48.9^{\circ} \mathrm{C}\left(120^{\circ} \mathrm{F}\right)$. The flow rate of the return water circulated by a water pump in the return line is manually controlled by a globe valve to give a water temperature rise of 10.56 to $13.33{ }^{\circ} \mathrm{C}$ (19 to $24{ }^{\circ} \mathrm{F}$ ) through the boiler under steady-state operating conditions.

For the domestic water heating tests, the boiler water inlet and outlet ports are connected to the outlet and inlet ports, respectively, of the immersed hot water coil in the tank. Hot water from the boiler is circulated through the coil by the circulating pump supplied by the manufacturer. As described in section 2 of this report, during the water heating tests, the on and off states of the boiler burner and the circulating pump are controlled by the cut-in and cut-out settings of the storage tank thermostat located just below the mid-height point of the tank. And, when the pump is in operation, the burner is also controlled by the boiler water high limit (burner off) and temperature differential below the high limit (burner on). The circulating pump is controlled only by the tank thermostat for the domestic water heating tests.

For the tests conducted at NIST, the appliance was installed in a high-bay laboratory space with controlled space temperature. A five-foot length of insulated stack was attached to the outlet of the boiler flue gas collar. The stack was located below an exhaust hood/vent pipe arrangement that was exhausted to outside. The natural gas supply to the boiler was from the local gas utility company. To maintain a near constant supply water temperature to the domestic water storage tank during the domestic water heating test, the same auxiliary water conditioning tank for the space heating test was used to supply the specified $14.4 \pm 1.1{ }^{\circ} \mathrm{C}\left(58 \pm 2{ }^{\circ} \mathrm{F}\right)$ domestic make-up water to the storage tank. The physical distance between the boiler and the storage tank was approximately $3 \mathrm{~m} \mathrm{(10} \mathrm{ft)} \mathrm{and} \mathrm{all} \mathrm{the} \mathrm{plumbing} \mathrm{components} \mathrm{were} \mathrm{insulated} \mathrm{to} \mathrm{minimize} \mathrm{the} \mathrm{heat}$ loss through the pipe.

Extensive instrumentation was installed on the test appliance as required by ASHRAE Standard 124. Temperature sensors included 24 gage type $T$ premium grade thermocouples for the inlet and outlet water temperatures at the boiler and at the domestic storage water tank, and at six equally spaced locations inside the hot water tank. Type $\mathrm{K}, 24$ gage, thermocouple grid was used for measuring the flue gas temperature in the flue stack $0.305 \mathrm{~m}(12 \mathrm{in.})$ above the boiler flue collar. Air temperature near the mid-height of the tank was measured with 24 gage type $T$ thermocouple. Water flow meters with electronic pulse generator were 
installed at the return side of the space heating loop and before the domestic water inlet port. The amount of natural gas flow to the boiler was measured with a commercial laboratory grade gas meter. The higher heating value of the gas was obtained from the local gas company. Gas temperature and pressure and the atmospheric pressure at the laboratory were monitored and recorded during the tests. In addition, samples of the flue gas (inside the 5-foot stack) were run through an ice-cooled condensing beaker and a desiccant container and analyzed by an infrared gas analyzer for the carbon dioxide concentration.

All of the thermocouples were calibrated before installation and the closest matched pairs were installed at the tank inlet and outlet sides of the boiler and the domestic water supply and outlet ports of the storage tank. In this way, an error of less than $0.2 \mathrm{C}\left(0.4^{\circ} \mathrm{F}\right)$ was obtained for the temperature rises across the boiler and across the storage tank. The infrared gas $\left(\mathrm{CO}_{2}\right)$ analyzer was calibrated with reference gases with known $\mathrm{CO}_{2}$ concentration of $2.992,5.2$, and 9.993 percent.

All sensors were connected to a data acquisition instrument and a desk top computer. The computer controlled the data scan rates, as well as the domestic water draw schedule by the use of the data acquisition and control application software supplied with the data acquisition instrument. For the 24-hour simulated use test, the data sampling rate was set at 15 seconds between scans during the hot water draw and at 5 to $15 \mathrm{~min}$ between scans during the standby period. For the space heating and the first-hour rating tests, the sampling rate was set at 15 seconds between scans. Data were stored on the computer's hard disk and afterward analyzed using a spreadsheet program.

\section{TEST PROCEDURE}

The test procedures for the family series of three gas-fired, induced draft boilers, each in combination with an identical $151.4 \mathrm{~L}$ (40 gal) indirectly heated domestic water storage tank, are described below.

\subsection{Space Heating - Steady-state and Cyclic Operation (Cool-down and Heat-up)}

As described before, the spacing heating tests followed the procedure specified by ANSI/ASHRAE Standard 103-1993 for the performance rating of residential boilers [2]. The appliance was operated manually with the burner and the water circulating pump on until a steady state was established. Steady state was established when the stack gas temperature did not vary by more than $1.7{ }^{\circ} \mathrm{C}$ ( 3 ${ }^{\circ}$ F) over a $30 \mathrm{~min}$ period. The space heating tests were conducted under the following conditions:

* Boiler inlet (return from the load) water temperature at 48.9 to $51.1{ }^{\circ} \mathrm{C}$ (120 to $\left.124^{\circ} \mathrm{F}\right)$.

* Boiler outlet (supply to the load) water temperature at 60 to $62.2{ }^{\circ} \mathrm{C}(140$ to $144^{\circ} \mathrm{F}$ ).

* Water flow rate through the boiler was adjusted manually by a control valve in the boiler water return line to maintain a steady-state temperature differential within 10.56 to $13.33^{\circ} \mathrm{C}$ (19 to $\left.24{ }^{\circ} \mathrm{F}\right)$ across the boiler specified above. The flow rates were estimated (based on an 
assumed steady state efficiency of 83 \%) to be approximately $22.7,34.07$ and $45.4 \mathrm{~L} / \mathrm{min}(6.0,9.0$ and $12.0 \mathrm{Gpm})$ for the three boilers with input capacity of 22,33 and $44 \mathrm{~kW}$, respectively. The actual flow rates during the tests were slightly different from the above values due to variations of the actual efficiency from the assumed value.

After steady state was established, the burner was run under the steady-state condition for $30 \mathrm{~min}$. Data for the natural gas volumetric flow over the $30 \mathrm{~min}$ period, the boiler water flow rate, flue gas temperature and flue gas $\mathrm{CO}_{2}$ concentration, boiler water outlet and return temperatures, and room temperature were monitored and recorded. After the $30 \mathrm{~min}$ steady-state test period, the gas burner and the pump were manually turned off and the boiler was allowed to cool down for $45 \mathrm{~min}$. During the cool-down period, flue gas temperatures at $3.75 \mathrm{~min}$ and at $22.5 \mathrm{~min}$ (into the cool-down period) were measured and recorded. After the cool-down test was completed, the burner and the pump were manually turned on for a $10 \mathrm{~min}$ heat-up period. Flue gas temperatures at $1.0 \mathrm{~min}$ and at $5.5 \mathrm{~min}$ (into the heat-up period) were measured. The space heating test was completed at the end of the heat-up period.

For the boiler used in this study, there is no continuous pilot and therefore, the annual fuel utilization efficiency AFUE is equal to the heating seasonal efficiency $\mathrm{EFF}_{\mathrm{hs}}$. The heating seasonal efficiency was computed by a program named AFUEBF which computerized the calculation procedure of ASHRAE Standard 103, using the flue gas temperature and $\mathrm{CO}_{2}$ concentration test data obtained during the steady-state, cool-down and heat-up tests.

\subsection{Domestic Water Heating}

\subsubsection{Setting Storage Tank Thermostat}

The domestic water heating tests for Type I integrated appliance require the setting of the thermostat in the storage tank which controls the cut-in and cutout of the boiler burner and the circulation pump during the hot water draw and standby tests.

The storage tank water temperature is specified to be set at $57.2 \pm 2.8{ }^{\circ} \mathrm{C}(135$ $\pm 5^{\circ} \mathrm{F}$ ) for pump and burner cut-out. To set this temperature, the tank is filled with cold water and the boiler and the circulation pump are turned on until the tank thermostat reaches the cut-out setting and stops the pump. The mean tank temperature is determined as the average of the six thermocouples in tank. If the mean tank temperature is within the range of $57.2 \pm 2.8{ }^{\circ} \mathrm{C}\left(135 \pm 5{ }^{\circ} \mathrm{F}\right)$, the thermostat is set. If not, the unit is turned off, the thermostat is adjusted, the tank is emptied and refilled with cold water and the test is started again. This process is repeated until the mean tank temperature at thermostat cut-out is at the correct setting. During the above process, the boiler water high limit control is set at $82.2 \pm 1.1{ }^{\circ} \mathrm{C}\left(180 \pm 2{ }^{\circ} \mathrm{F}\right)$.

The temperature differential for the tank thermostat cut-in (where the boiler burner and water pump come on) is set by the manufacturer at a fixed $5.5{ }^{\circ} \mathrm{C}(10$ ${ }^{\circ}$ F) below the tank thermostat cut-out setting. Once set, the tank thermostat cutout setting was not changed and was used in the water heating tests for all three boiler/storage tank combinations. 
As described previously, during the water heating test, the circulation pump and the burner are controlled by the storage tank thermostat cut-in (on) and cut-out (off) settings. In addition, the boiler water temperature controller will also turn the burner off if the boiler high limit setting is reached before the tank thermostat cut-out setting is reached. The controller will turn the burner on when the boiler water temperature drops below the temperature differential setting (fixed at $11.1{ }^{\circ} \mathrm{C}\left(20^{\circ} \mathrm{F}\right)$ below the high limit) as long as the circulation pump is running. The pump is only controlled by the tank thermostat. Once turned on, the pump continues to run until the tank thermostat cut-out setting is reached. The burner will be turned off when the pump is turned off.

\subsubsection{Simulated 24 -Hour Use Test}

The simulated 24-hour use test for rating a boiler as a domestic water heater was carried out according to the procedure specified in ASHRAE standard 124 for Type I integrated appliances. A slight departure from the ASHRAE standard 124 procedure for this test was that the six hourly water draws were performed before the 18-hour standby test instead of after the 18-hour standby period. This was done to conform to the Department of Energy test procedure for storage type domestic water heaters. This change should cause no significant changes in the results since the starting and ending conditions of the two procedures are the same. The test boiler was operated for a conditioning period which consisted of two successive water draws of $40.5 \mathrm{~L}(10.7 \mathrm{gal})$ each and tank recovery cycle (pump and burner cut-in, storage tank recovery, and tank thermostat cut-out) before the 24-hour test was started. The first of the six draws followed immediately after the thermostat cut-off, which was also the start of the 24-hour test time clock. The water flow rate during the draw was fixed at $0.19 \pm 0.016$ $\mathrm{L} / \mathrm{s}(3 \pm 0.25 \mathrm{Gpm})$. The total water draw volume over the six hourly draw periods was $243.4 \mathrm{~L}(64.3 \mathrm{gal})$. After the six hourly water draws and the burner recovery that follows the final draw were completed, the approximately $18 \mathrm{~h}(24 \mathrm{~h}$ minus the elapse time when the last hourly draw/recovery is completed) standby period was initiated. During the standby period, the tank thermostat controlled the pump and the burner on/off operations. The boiler water high limit and temperature differential controller also controlled the burner operation when the pump was on. At the end of the $24 \mathrm{~h}$ period (from the beginning of the first water draw), the pump and the burner were manually turned on and operated until the mean tank temperature reached its value at the beginning of the first water draw. The test was then completed and stopped. During the test, the storage tank makeup water temperature was set at $14.4 \pm 1.1{ }^{\circ} \mathrm{C}\left(58 \pm 2{ }^{\circ} \mathrm{F}\right)$. The tank coil inlet and outlet temperatures, boiler water outlet and return temperatures, flue gas temperature, and the gas fuel consumption were recorded and output to a data file. The energy factor was calculated from these data using a spreadsheet program and the equations specified in ASHRAE standard 124.

\subsubsection{First-Hour Rating Test}

The first-hour rating test was carried out according to the procedure specified in ASHRAE standard 124 for Type I integrated appliances. The procedure is as following:

1. Run the boiler and the circulation pump (to storage tank) until the tank thermostat cut-out is reached. 
2. Beginning the first-hour draw test clock. Start drawing domestic water at $0.19 \pm 0.016 \mathrm{~L} / \mathrm{s}(3 \pm 0.25 \mathrm{Gpm})$. Record the maximum tank outlet temperature during this first draw as $\mathrm{T}_{\text {o(max) }}$. Continue the water draw at the fixed rate until the tank outlet water temperature decreases to 13.9 ${ }^{\circ} \mathrm{C}\left(25^{\circ} \mathrm{F}\right)$ below the $\mathrm{T}_{\circ(\max )}$. Record the length of time the draw is on. Then stop the draw and wait for the recovery to complete. (During the water draw, the cut-in of the pump and burner can occur before the water temperature decreased to $13.9^{\circ} \mathrm{C}$ below $\mathrm{T}_{\mathrm{O}(\max )}$. )

3. Record the outlet and inlet boiler water and domestic water temperatures beginning 15 seconds after the start of the draw, and continuing at $5 \mathrm{~s}$ intervals.

4. Wait for the tank thermostat to cut out which will stop the pump (and the burner if it is on). After the thermostat cuts out, begin the draw again as in step 2. Continue the draw until the outlet water temperature decreases to $13.9^{\circ} \mathrm{C}\left(25{ }^{\circ} \mathrm{F}\right)$ below the $\mathrm{T}_{\mathrm{o}(\max )}$ recorded at the beginning of this draw, then stop the draw and record the length of time the draw is on.

5. Continue the process until one hour has elapsed from the beginning of the first draw.

6. If a draw is currently taken place at the end of the one hour, continue the draw until the outlet water temperature decreases to $13.9{ }^{\circ} \mathrm{C}\left(25{ }^{\circ} \mathrm{F}\right)$ below the $T_{o(\max )}$ recorded at the beginning of this draw. Then stop the draw and record the length of time the draw is on.

7. If a draw is not taking place at the end of one hour, wait until the thermostat cuts out. Then start a final draw. Continue the draw until the outlet water temperature decreases to $13.9^{\circ} \mathrm{C}\left(25^{\circ} \mathrm{F}\right)$ below the $\mathrm{T}_{\mathrm{O}}(\max )$ recorded at the beginning of this draw. Then stop the draw and record the length of time the draw is on.

8. Record the total length of time from the beginning of the first draw to the end of the last draw. Determine the volume of the total water withdrawn in liters (gallons). This completes the first-hour rating test. The first-hour rating was calculated from the recorded data using the equations specified in ASHRAE Standard 124.

\section{TEST RESULTS AND DISCUSSION}

The three gas-fired, induced draft boilers with input capacities of 22,33 and $44 \mathrm{~kW}(75000,112500$ and $150000 \mathrm{Btu} / \mathrm{h})$, each combined with the same storage tank with a hot water coil at the bottom of the hot water storage tank, were tested in accordance with the procedure described in section 4 of this report. Each of the tests was repeated once. The results from the tests are discussed below.

\subsection{Space Heating Tests (Steady-state, Cool-down and Heat-up Tests)}

The flue gas temperatures and $\mathrm{CO}_{2}$ concentration data from the space heating tests were input to the AFUEBF computer program which is a computerized version of the calculation procedure for boiler steady-state and annual fuel utilization efficiencies calculation specified in ASHRAE Standard 103. The steady-state efficiency and the annual fuel utilization efficiency (AFUE) were computed by the program. The average steady-state efficiencies (average of two tests) were $80.88 \%, 81.58$ and $82.78 \%$ for the 22,33 and $44 \mathrm{~kW}$ boilers, respectively. The 
corresponding average AFUE values were $79.3 \%, 77.8 \%$ and $77.0 \%$. It is seen that the variations in the space heating efficiencies among the three boilers were fairly small. This small variation in the steady-state efficiency and AFUE values showed that linear interpolation of both steady-state efficiency and AFUE with respect to input capacity within a family series of boilers can be used to predict the AFUE values for other units in the family series with input rates between the minimum and maximum rates tested.

\subsection{Simulated Domestic Hot Water Use Test}

Sample results from the simulated use test are presented in Figures 2,3 and 4 for the boiler with an input capacity of $33 \mathrm{~kW}(112500 \mathrm{Btu} / \mathrm{h})$. Figure 2 shows the variations in mean tank water temperature, boiler outlet water temperature, domestic water outlet temperature, and the flue gas temperature during the first $6 \mathrm{~h}$ of the 24-hour simulated water use test. It is seen that during the first $6 \mathrm{~h}$, when $40.5 \mathrm{~L}$ ( $10.7 \mathrm{gal})$ of the domestic water were drawn at the rate of 0.19 $\mathrm{L} / \mathrm{s}$ ( $3 \mathrm{Gpm}$ ) at the beginning of each hour, the circulation pump and the burner came on only during the second, fourth and sixth hourly draw periods. This is because that the water temperature in the storage tank was well stratified so that for the first $40.5 \mathrm{I}$ (10.7 gal) of water drawn from a fully heated tank, the water temperature at the thermostat location did not decrease to below the pump and burner cut-in setting. The thermostat cut-in occurred only when $40.5 \mathrm{I}$ more water were drawn during the second water draw period. Once the thermostat cut-in occurred, the hot water coil at the bottom of the tank would then heat the whole tank of water to the uniform cut-out temperature, and the process would repeat itself over every two water draws. Figure 3 illustrates the temperature variations during the entire $24 \mathrm{~h}$ period, including the $18 \mathrm{~h}$ standby period. During the $18 \mathrm{~h}$ standby period, the tank went through one recovery at between the 21 and 22 hour period, when the water temperature at the tank thermostat decreased to the cut-in temperature of between 51.1 to $51.7^{\circ} \mathrm{C}$ (124 to $125{ }^{\circ} \mathrm{F}$ ). Figure 4 shows the accumulated flow volumes of the domestic water withdrawn, the boiler water through the hot water coil, and the fuel gas flow to the burner, respectively. The figure is shown here to illustrate the activity of the hourly water-draw during the first $6 \mathrm{~h}$, the on and off-time of the circulation pump, and the on and off-time of the burner. The horizontal lines are periods of inactivity. The pump on and off-time corresponded to the thermostat cut-in and cut-out time, while the on and off-time of the burner indicated the cut-in and cut-out time of both the tank thermostat and the boiler high limit and the temperature differential controller. Whenever the boiler temperature dropped by $11.1{ }^{\circ} \mathrm{C}\left(20^{\circ} \mathrm{F}\right)$ below the high limit setting, the burner came on to heat the boiler water to the high limit setting of 81.1 to $83.3^{\circ} \mathrm{C}$ (178 to $182{ }^{\circ} \mathrm{F}$ ). This temperature assures that hot water from the boiler is available to heat the water in the storage tank as long as the circulation pump is on (between the period of tank thermostat cut-in and cut-out). It is noted that the actual units of the volume flow are not shown since the amounts are immaterial for determining the status of the flow conditions.

The results for the other two boiler/storage tank combinations are similar to those in Figures 2 to 4 and are, therefore, not shown. 
Sample results from the first-hour rating test is presented in Figures 5,6 and 7 for the boiler with the input capacity of $33 \mathrm{~kW}(112500 \mathrm{Btu} / \mathrm{h}), 22 \mathrm{~kW}(75000$ $\mathrm{Btu} / \mathrm{h})$, and $44 \mathrm{~kW}(150000 \mathrm{Btu} / \mathrm{h})$, respectively; and the calculated first-hour rating as a function of the rated input of the three boilers is shown in Figure 8. Figure 5 shows the variation in the boiler flue gas temperature, the mean storage tank water temperature, and the storage tank outlet water temperature during the water draws. It can be seen that approximately two and one-half (2 $1 / 2$ ) draws were made during the first hour and three draws were made during the first-hour test period. This is because, according to the test procedure in ASHRAE Standard 124, if a draw is in progress at the end of one hour (from the beginning of the test), the draw is to continue until the outlet water temperature decreased to $13.9{ }^{\circ} \mathrm{C}\left(25^{\circ} \mathrm{F}\right)$ below the maximum outlet temperature $\left(\mathrm{T}_{\mathrm{o}(\max )}\right)$ recorded at the beginning of the draw. The same number of draws (3) were also recorded for the other two boilers during the first-hour rating test period, and the total volume of the water drawn are approximately the same. However, the length of time it took for the three draws to complete decreased with the increase in the boiler input capacity and hence faster tank recovery between draws. This resulted in a greater first-hour rating for the larger capacity boilers since the first-hour rating is the total volume of hot water drawn divided by the total elapse time from the beginning to the end of the test period. The total volumes drawn for each of the three boiler/storage tank combinations, together with their calculated first-hour ratings are tabulated in Table 1. As mentioned at the beginning of this section, each of the tests was repeated once and Table 1 gives the results of the two tests and the averaged first-hour ratings on the basis of the two tests. Figure 5 shows that even though the mean tank temperature decreased during the period of water draw because of the cold make-up water entering from bottom of the tank, the temperature of the outlet hot water remained unchanged during most of the draw period, indicating that there was no mixing of the hot water and the make-up water during the draw.

The variations of the flue gas temperature (Fig. 5) indicates that the boiler cycled on and off under the control of the tank thermostat (located near the midsection of the tank) as well as by the high limit (and temperature differential) controller of the boiler when the circulating pump was on. The burner and the pump were turned on about midway through the first draw (around $0.1 \mathrm{hr}$ ) by the tank thermostat. The burner was turned off by the boiler water temperature highlimit control (around $0.28 \mathrm{hr}$ ) while the pump continued to circulate the boiler water through the heat exchanger in the tank. The burner was then turned on and off twice more during the first tank recovery by the boiler water temperature differential and high-limit controller. The pump was turned off by the tank thermostat when the recovery was completed (around $0.46 \mathrm{hr}$ ), and the boiler remained off when the pump was off. The cycle was then repeated midway through the second draw.

Figure 6 shows the variation of the flue gas temperature for a boiler with the smaller input capacity $(22 \mathrm{~kW})$. It took this boiler a longer time to reach its high limit setting than the higher capacity one, and the burner did not cycle between the on setting and high limit (off) setting (temperature differential) during the first draw. It was turned on only once more by the boiler temperature 
controller (on setting) and was quickly turned off by the tank thermostat at the completion of the second tank recovery. This indicates that, for domestic hot water heating purpose, a smaller-size boiler in a family series of combination system of boiler/storage tank with an identical storage tank should have a higher water heating efficiency because there will be less burner on/off cycles and hence a smaller daily off-cycle loss. However, for the smaller capacity boiler, the tank recovery time was longer. The reverse was true for a boiler with a larger capacity $(44 \mathrm{~kW})$ as was illustrated in Figure 7.

TABLE 1

Results of first-hour rating tests

\begin{tabular}{|c|c|c|c|c|c|}
\hline $\begin{array}{l}\text { Boiler } \\
\text { input }\end{array}$ & \multicolumn{2}{|c|}{$\begin{array}{c}\text { Total volume drawn } \\
(\mathrm{L})\end{array}$} & \multicolumn{3}{|c|}{$\begin{array}{r}\text { First-hour rating } \\
(\mathrm{L})\end{array}$} \\
\hline$(\mathrm{kW})$ & Test 1 & Test 2 & Test 1 & Test 2 & Average \\
\hline 22 & 3925 & 3895 & 3172 & 3206 & 318,9 \\
\hline 33 & 392.5 & 397.4 & 341.6 & 341.5 & 341.6 \\
\hline 44 & 390.7 & 391.8 & 369.4 & 371.7 & 370.6 \\
\hline
\end{tabular}

Figure 8 shows a plot (the average of two tests) of the first-hour rating as a function of the boiler input capacity of a boiler/storage tank combination appliance. The variation is nearly linear, suggesting that, although only a limited number of boilers were investigated, it appears that there is a linear relationship between first-hour rating and boiler input capacity. These results suggest that it is possible to linearly interpolate the test results for the first-hour ratings of a family series of boilers with an identical size storage tank on the basis of tests from two different capacity boilers in the family series. The small concave upward of the plot will make the predicted first-hour rating slightly larger than it should be if the smallest and the largest boilers in the family series are tested and used for the interpolation. This overestimation may be minimized if two intermediate size units in the family series are tested and interpolation and extrapolation are used to predict the performance of the other units inside and outside the size range of the two tested units. By this method, the predicted performance would be slightly higher for the units within the size range of the two tested units and slightly lower for the units outside the size range of the tested units. However, both the over and under-estimation would be kept close to a minimum and within an acceptable range.

\subsection{Energy Factor}

Figure 9 presents a plot (the average of two tests) of the energy factor (EF, bottom curve) of the three boiler/storage tank systems calculated from results of the 24-hour simulated use test as prescribed in ANSI/ASHRAE Standard 124 at a total daily hot water draw of $243.4 \mathrm{~L}(64.3 \mathrm{gal})$. The energy factor was calculated as the ratio of the net energy delivered as hot water over the six hourly draws to the total energy input to the boiler over the 24-hour simulated 
use test period. The $24 \mathrm{~h}$ test period consisted of six hourly draws with a standby period following each hourly draw and recovery plus the final $18 \mathrm{~h}$ standby. It can be seen that the energy factor decreased with increasing burner input capacity. The rate of decrease was nearly linear. Thus, conducting tests to determine the energy factor of two combination appliances within a family series that use an identical sized storage tank and then using linear interpolation to determine the energy factors for other boilers within the family series appears reasonable. Again, to minimize the error caused by linear approximation over the entire size range of the family series of boilers, two intermediate size units instead of the smallest and largest size units should be tested. Interpolation or extrapolation is then used to predict the performance of the other units.

\subsection{Space Heating Efficiency and Combined Annual Efficiency}

Figure 9 also presents the results (the average values of two tests) of the steady-state efficiency, $\mathbf{E F F}_{\mathrm{ss}}$, the seasonal space heating efficiency, $\mathrm{EFF}_{\mathrm{hs}}$ (equal to the annual fuel utilization efficiency, AFUE, for boilers with no pilot light) and the combined annual efficiency, CAE, of the three combination appliances. In order to compare the relative magnitude of the efficiency values versus the energy factor values, the values of all three efficiencies in Figure 9 are expressed in fractions, not percent. The combined annual efficiency (CAE) is defined in ANSI/ASHRAE Standard 124 as the rating descriptor for Type I (and Type II) combination appliances. Each CAE was determined using the appropriate steady-state efficiency, calculated space heating seasonal efficiency $\mathbf{E F F}_{\mathrm{hs}}$, calculated energy factor EF and the procedure specified in ANSI/ASHRAE Standard 124 for calculating CAE. The calculation procedure is included in the appendix of this report for reference. It can be seen from Figure 9 that the CAE as well as $\mathrm{EFF}_{\mathrm{hs}}$ and $\mathrm{EFF}_{\mathrm{ss}}$ also vary nearly linearly with boiler capacity, suggesting that linear interpolation/extrapolation is appropriate.

The values of the steady-state efficiency $\mathrm{EFF}_{\mathrm{ss}}$, the space heating seasonal efficiency $\mathbf{E F F}_{\mathrm{hs}}$ (or $\mathrm{AFUE}$ ), the energy factor $\mathrm{EF}$, and the combined annual efficiency CAE are tabulated in the following table for the three boilers tested.

TABLE 2

Results of space heating and water heating tests

\begin{tabular}{|c|c|c|c|c|c|c|c|c|}
\hline \multirow{3}{*}{$\begin{array}{l}\text { Boiler } \\
\text { input } \\
\text { (kw) }\end{array}$} & \multicolumn{2}{|c|}{$\mathrm{EFF}_{\mathrm{SS}}\left(\frac{q}{8}\right)$} & \multicolumn{2}{|c|}{ EFF $_{\text {hs }}\left(\frac{o}{\partial}\right)$} & \multicolumn{2}{|c|}{ EF } & \multicolumn{2}{|c|}{$\operatorname{CAE}\left(\frac{\circ}{6}\right)$} \\
\hline & Test & No. & Test & No. & Test & No. & Test & No. \\
\hline & 1 & 2 & 1 & 2 & 1 & 2 & 1 & 2 \\
\hline \multicolumn{9}{|c|}{ - - - - - - - - - - - - - - } \\
\hline 22 . & 82.92 & 82.64 & 79.53 & 79.05 & 0.4833 & 0.4920 & 76.09 & 76.24 \\
\hline 33. & 81.53 & 81.64 & 77.80 & 77.79 & 0.4679 & 0.4586 & 75.45 & 75.33 \\
\hline 44. & 80.86 & 80.88 & 76.84 & 76.99 & 0.4392 & 0.4450 & 74.85 & 74.92 \\
\hline
\end{tabular}




\section{SUMMARY AND CONCLUSIONS}

Laboratory tests were conducted on a family series of Type I combination appliances, consisting of three sizes of gas-fired boilers $(22,33$ and $44 \mathrm{~kW})$ and a single hot water storage tank and coil (within the tank). The test results were used to evaluate a linear interpolating scheme for predicting the Energy Factor and the Combined Annual Efficiency of the family series of combined space/water heating appliances using only the test results from two units of different capacities within the series. The conditions for the testing of space heating and domestic water heating were those specified in ANSI/ASHRAE Standard 124-1991. The energy factors (EF) for domestic water heating and the combined annual efficiencies (CAE) were calculated using the procedures in ANSI/ASHRAE standard 124. The total daily domestic water draws of $243.4 \mathrm{~L}$ (64.3 gal) was used.

The results showed that the annual fuel utilization efficiency (AFUE) for space heating (represented by the seasonal space heating efficiency $E_{F F} F_{h s}$ ) for the three boilers differed by approximately 2.5 percentage points, with the smaller boiler having a higher efficiency. The energy factor (EF) also depended on the size of the boilers for the same daily water draw, with the smallest capacity boiler $(22 \mathrm{~kW})$ giving an energy factor by near 5 percentage points higher than the largest capacity boiler $(44 \mathrm{~kW})$. Further, for the same hot water draw, the energy factor (EF) was an approximate linear function of the boiler input capacity. Therefore, linear interpolation of the EF is possible for a constant daily hot water draw.

The results also showed that the combined annual efficiency (CAE) varied by approximately 1.6 percentage points among the three boilers having the same daily water draw. Thus, a single linear interpolation appears adequate for determining the combined annual efficiency, CAE.

The small concave upward of the plotted results from the three test boilers indicated that the predicted results based on linear interpolation will be slightly larger than it should be if the smallest and the largest boilers in the family series are tested and used for the interpolation of other intermediate size units in-between. This over-estimation can be minimized if two intermediate size units in the family series are tested and interpolation and extrapolation are used to predict the performance of the other units inside and outside the size range of the two tested units. The predicted performance would be slightly higher for the units within the size range of the two tested units and slightly lower for the units outside the size range of the tested units. However, both the over and under-estimation would be kept close to a minimum and within an acceptable range. 


\section{REFERENCES}

1. ANSI/ASHRAE Standard 124-1991, "Method of Testing for Rating Combination Space Heating/Water Heating Appliances", ASHRAE, 1991

2. ANSI/ASHRAE 103-1993, "Methods of Testing for Annual Fuel Utilization Efficiency of Residential Central Furnaces and Boilers", ASHRAE, 1993

3. Federal Register, DOE 10 CFR Part 430, "Uniform Test Method for Measuring the Energy Consumption of Water Heaters", Appendix E to Subpart B of Part 430, October 17, 1990

4. Park, C; Kelly, G.E., "A Study on the Performance of Residential Boilers for Space and Domestic Hot water Heating", NISTIR 89-4104, June, 1989

5. Liu, S.T.; Kelly, G.E., "Predicting the Energy Performance Ratings of a Family of Type I Combination Appliances", NISTIR 5250, August, 1993

6. Tree, D.R., "Error Analysis of Methods of Testing for Annual Fuel Utilization Efficiency of Residential Central Furnaces and Boilers", Report on Research Project No. 43NANB117252, Purdue Research Foundation, Purdue University, February, 1993 


\section{APPENDIX A}

Calculation of Combined Annual Efficiency (CAE) by the ANSI/ASHRAE Standard 1241991 Procedure

The following computation of the Combined Annual Efficiency is from Section 11 of ASHRAE Standard 124.

$\mathrm{EFF}_{\text {ss }}=$ Steady-state space heating efficiency from ASHRAE Std. 103-1993, $\frac{2}{8}$

$\mathrm{EFF}_{\mathrm{hs}}=$ Space heating seasonal efficiency from ASHRAE std. 103-1993, $\frac{\%}{2}$

$\mathrm{EF} \quad=$ Energy factor from DOE $10 \mathrm{CFR}$ Part 430 procedure

$Q_{\text {in }}=$ Boiler nameplate rated energy input rate

$\mathrm{T}_{\mathrm{t}}=57.22^{\circ} \mathrm{C}\left(135^{\circ} \mathrm{F}\right)=$ nominal tank temperature

$\mathrm{T}_{c} \quad=14.4{ }^{\circ} \mathrm{C}\left(58^{\circ} \mathrm{F}\right)=$ nominal cold water supply temperature

$\mathrm{d} \quad=$ density of water at measured tank outlet temperature

$\mathrm{U} \quad=243.4 \mathrm{~L}(64.3 \mathrm{gal})=$ daily domestic hot water consumption

$\mathrm{R} \quad$ = national average, ratio non-heating season days to heating season days

1. Heating Season Space Heating Factor (SHF):

$\mathrm{SHF}=0.225\left(\mathrm{EFF}_{\mathrm{Ss}} / \mathrm{EFF}_{\mathrm{hs}}\right)$

2. Heating Season Water Heating Factor (WHF):

$\mathrm{WHF}=U(\mathrm{~d})\left(\mathrm{T}_{t}-\mathrm{T}_{\mathrm{c}}\right) /\left[24\left(Q_{\mathrm{in}}\right)\left(\mathrm{EFF}_{\mathrm{ss}} / 100\right)\right]$

3. Non-heating Season Factor (NHF):

$N H F=U(d)\left(T_{t}-T_{c}\right) /\left[24\left(Q_{i n}\right)(E F)\right]$

4. Combined Annual Efficiency (CAE):

$\mathrm{CAE}=\left[\mathrm{SHF}\left(\mathrm{EFF}_{\mathrm{hS}} / 100\right)+\mathrm{WHF}\left(\mathrm{EFF}_{\mathrm{SS}} / 100\right)+\mathrm{R}(\mathrm{NHF})(\mathrm{EF})\right] /[(\mathrm{SHF}+\mathrm{WHF}+\mathrm{R}(\mathrm{NHF})]$ 


\section{Appendix B}

\section{Measurement Uncertainty}

The measured variables used to calculate the energy factor in the 24-hour simulated use test are: the water flow rate and the inlet and outlet water temperatures to determine the boiler (to hot water) output energy, and the total volume input of the gas fuel, the gas higher heating value, gas pressure, and gas temperature to determine the boiler input energy. The uncertainty of the turbine meter in the water flow rate measurement was estimated at equal to or less than $\pm 1 \%$. The thermocouples for the inlet and outlet DHW temperatures measurement were made from a single spool of precision thermocouple wire, and were calibrated to have a maximum inaccuracy of $\pm 0.6{ }^{\circ} \mathrm{C}$ over the temperature range of 5 to $95{ }^{\circ} \mathrm{C}$. Two closely matched thermocouples (with errors on the same side of the standard reference thermometer throughout the 5 to $95^{\circ} \mathrm{C}$ range) were installed for the DHW inlet and outlet temperature measurement, giving an inaccuracy in the temperature differential of less than $\pm 0.3{ }^{\circ} \mathrm{C}$, or $\pm 0.7 \%$ for the nominal temperature rise of $43^{\circ} \mathrm{C}\left(77^{\circ} \mathrm{F}\right)$. The gas meter was calibrated to have an inaccuracy of $\pm 0.5 \%$. The uncertainties of the higher heating value of the gas was estimated to be $\pm 1 \%$, the gas pressure $\pm 2 \%$, and the gas temperature (in absolute scale) $\pm 0.1 \%$. Based on these individual measurement uncertainties, the combined standard uncertainty of the calculated energy factor was $\pm 2.52 \%$.

In ANSI/ASHRAE Standard 103-1993 [2], the determination of the steady-state and heating seasonal efficiencies of the boilers in the space heating test is based on the heat loss method. The method involves a complex calculation procedure based on numerous assumptions. An error analysis of the method based on the maximum allowable errors in measurement specified in the standard for each of the measured variables was obtained recently by Prof. David R. Tree of the Purdue University under contract to NIST [6]. The error analysis was performed by running a computerized version of the calculation procedure in ANSI/ASHRAE Standard 103 to determine the overall uncertainty on the calculated efficiency due to the effect of uncertainties of the maximum allowed errors in each of the measured input variables (room and flue gas temperatures during the steady-state, cool-down and heat-up tests, flue gas $\mathrm{CO}_{2}$ concentration). The resulting uncertainty was determined to be \pm 0.22 percent for the steady-state efficiency and $\pm 0.42 \frac{2}{6}$ for the heating seasonal efficiency for an induced draft unit [6].

On the basis of the above uncertainty values of $\pm 0.22 \%$ and $\pm 0.42 \%$ for the steadystate efficiency and the heating seasonal efficiency, respectively, and with the uncertainty value of $\pm 2.52 \%$ for the energy factor, the combined standard uncertainty for the combined annual efficiency (CAE) was estimated to be $\pm 2.56 \%$. 


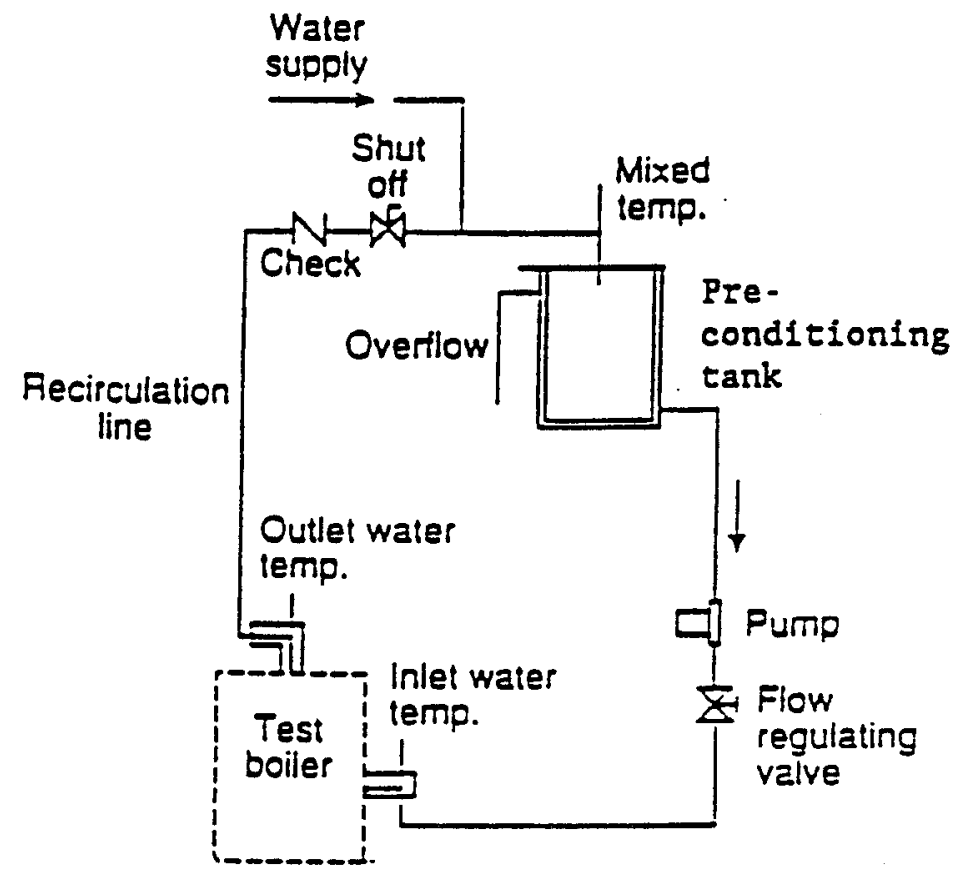

\section{Piping arrangement for space heating test}

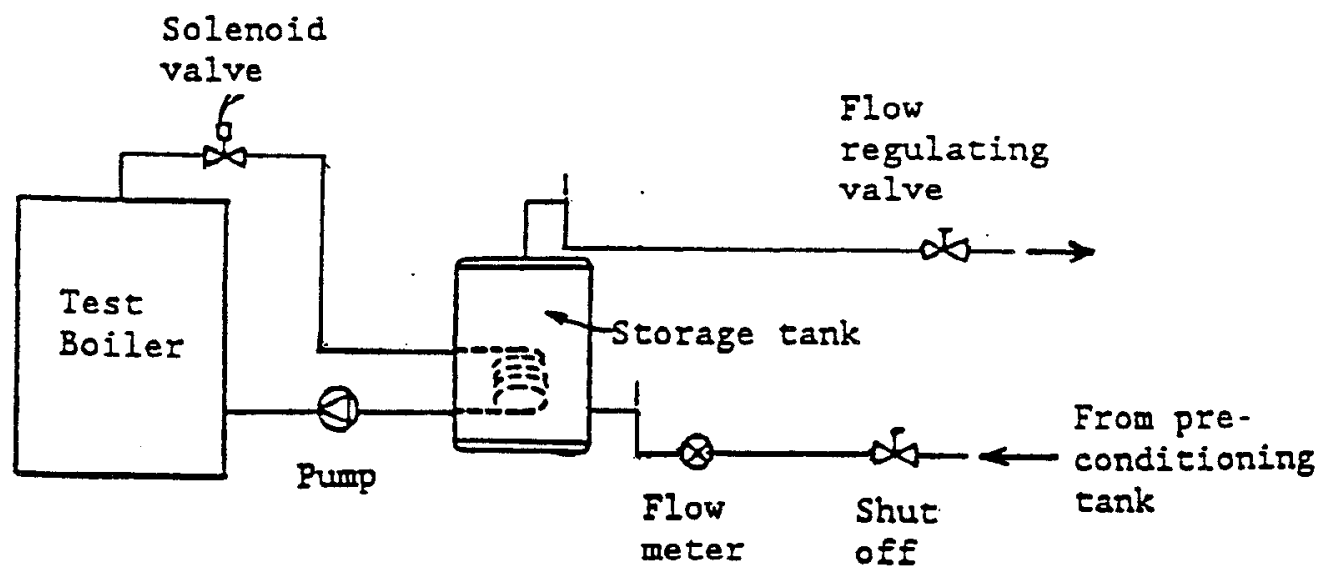

Piping arrangement for domestic water heating test

Fig. 1 Schematic of a boiler with domestic water storage tank 


\section{Simulated 24-Hr Use Test - $33 \mathrm{~kW}$ Boiler}

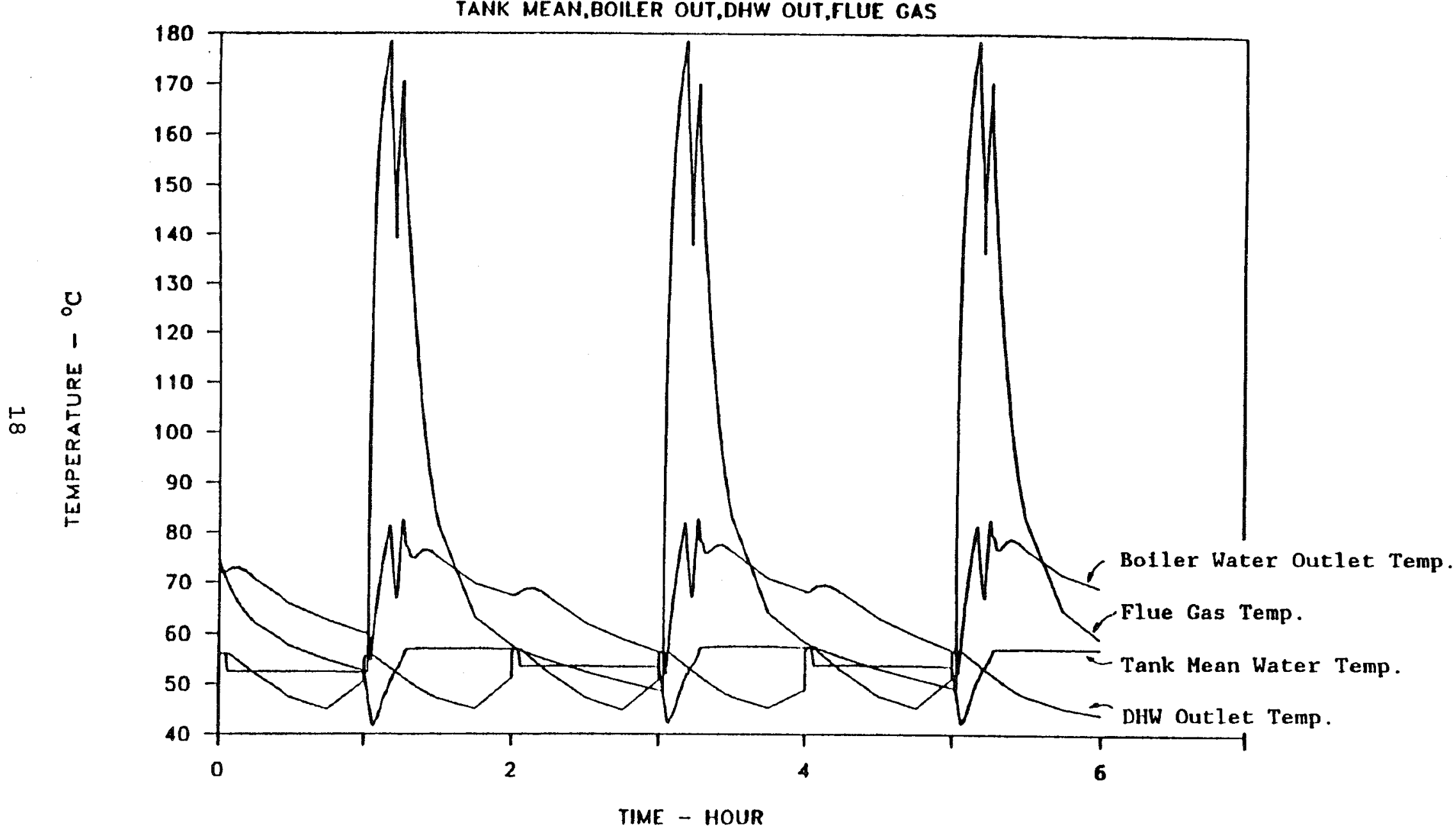

FIg. 2 Flue gas, boller outlet and domestlc water outlet temperature under 24-hour simulated use test condition (over water draw perlod) 


\section{Simulated 24-Hr Use Test - $33 \mathrm{~kW}$ Boiler}

TANK MEAN,BOILER OUT,DHW OUT,FLUE GAS

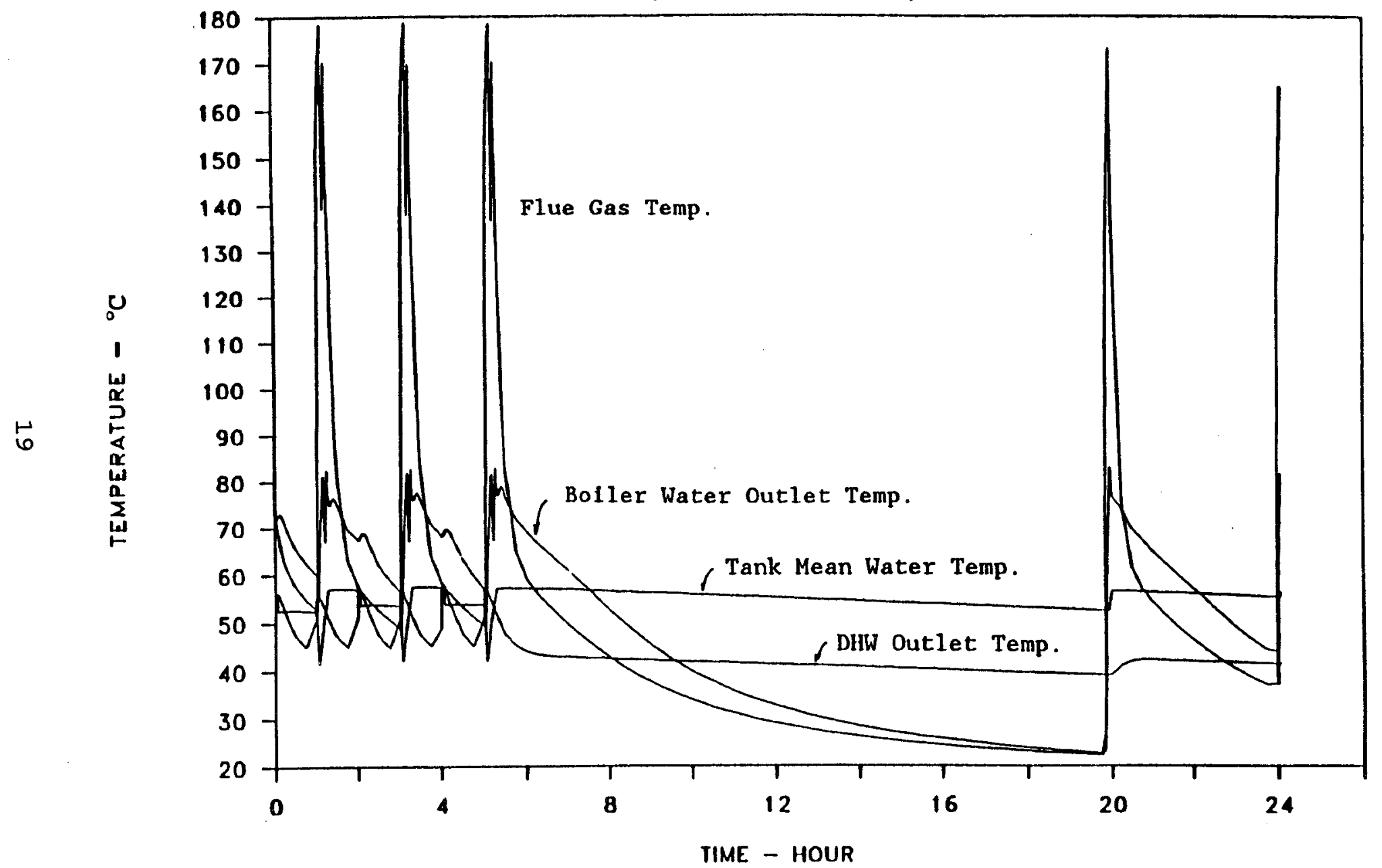

Fig. 3 Flue gas, bofler outlet and domestic water outlet temperature under 24-hour simulated use test condition (over the 24-hour period) 


\section{Simulated 24-Hr Use Test - $33 \mathrm{~kW}$ Boiler}

CUMULATIVE FLOW - GAS,DHW COIL,DHW DRAW

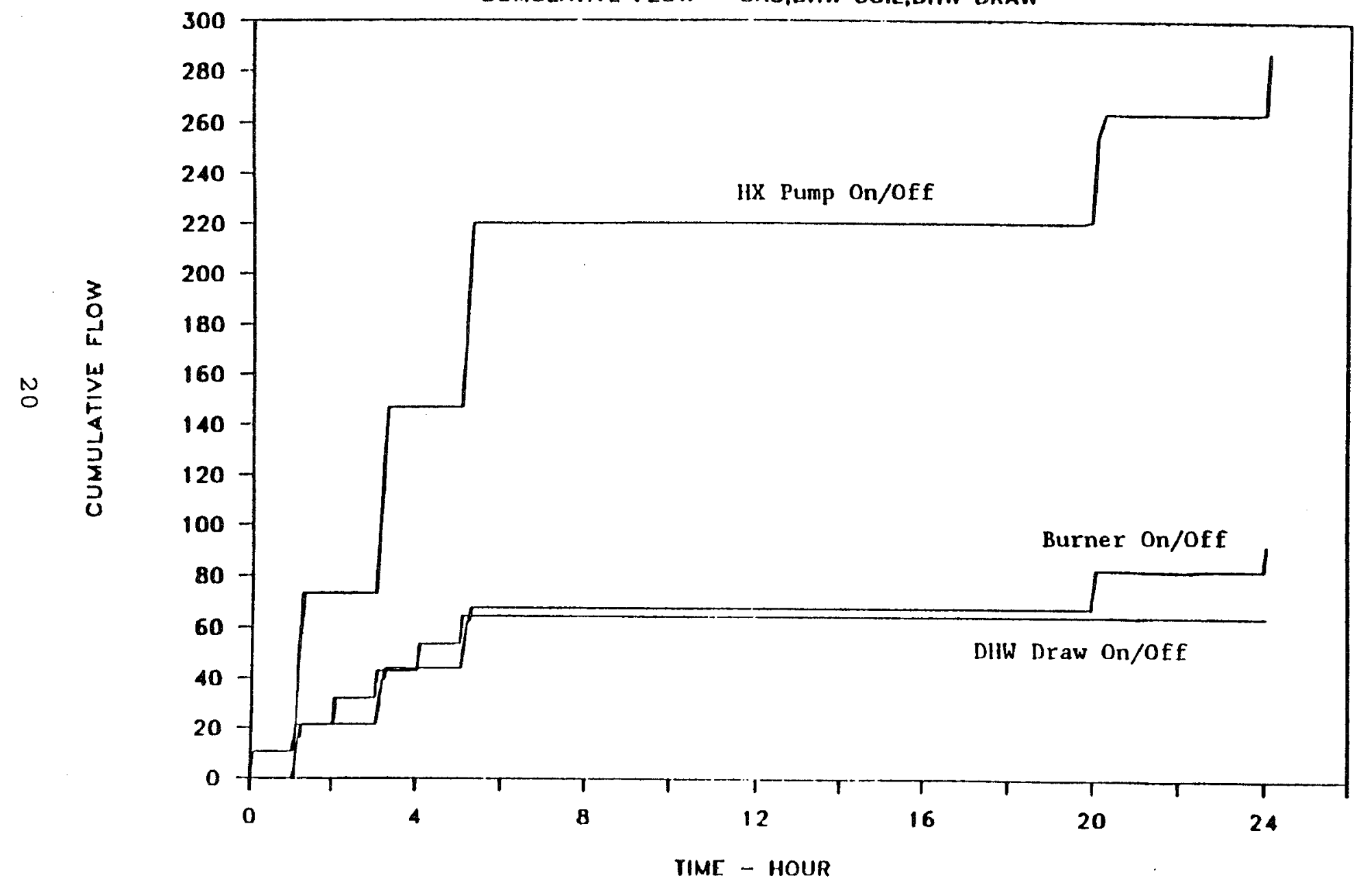

Fig. 4 On and off status of the domestic water outlet valve, fuel gas valve and boller water circulation pump during 24 -hour imulated use test over the 24 -hour perlod 


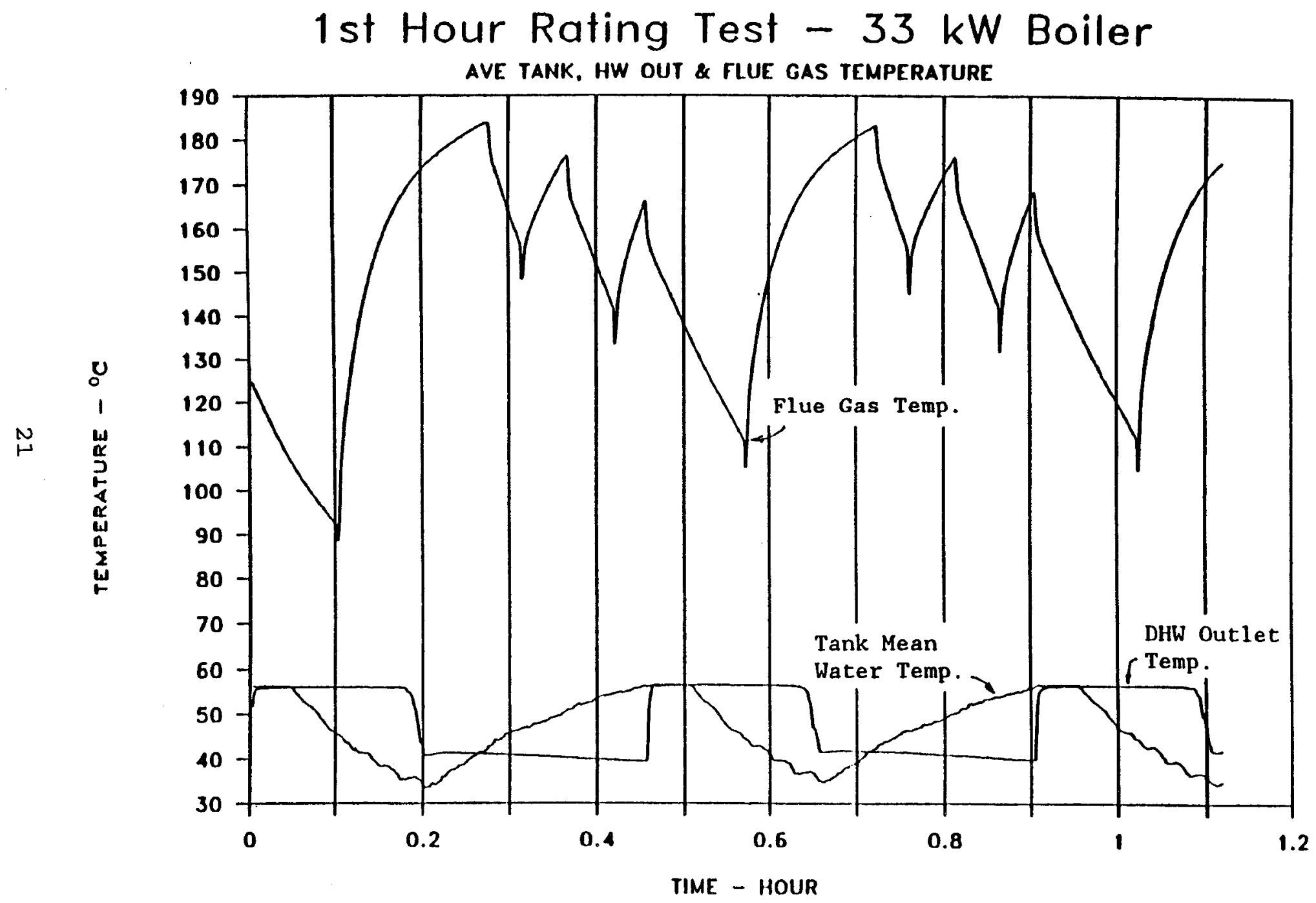

FIg. 5 Flue gas, tank mean water and domestic water outlet cemperature during the first hour rating test ( $33 \mathrm{~kW}$ input) 
1 st Hour Rating Test \#2 - $22 \mathrm{~kW}$ Boiler AVE TANK, HW OUT \& FLUE GAS TEMPERATURE

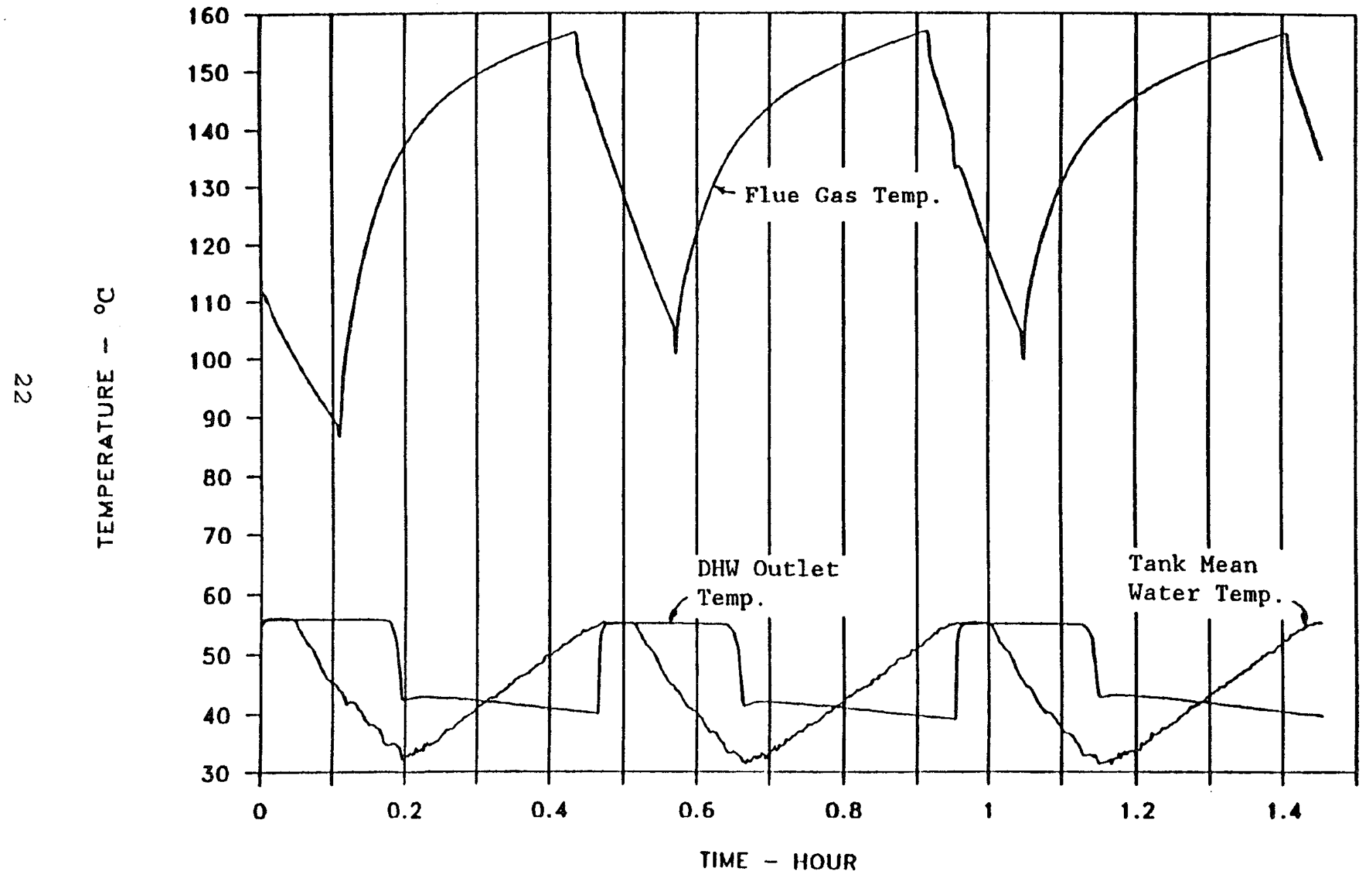

Fig. 6 Flue gas, tank mean water and domestic water outlet temperature during the first hour rating test (22 kW input) 
1 st Hour Rating Test \#2 - $44 \mathrm{~kW}$ Boiler AVE TANK, HW OUT \& FLUE GAS TEMPERATURE

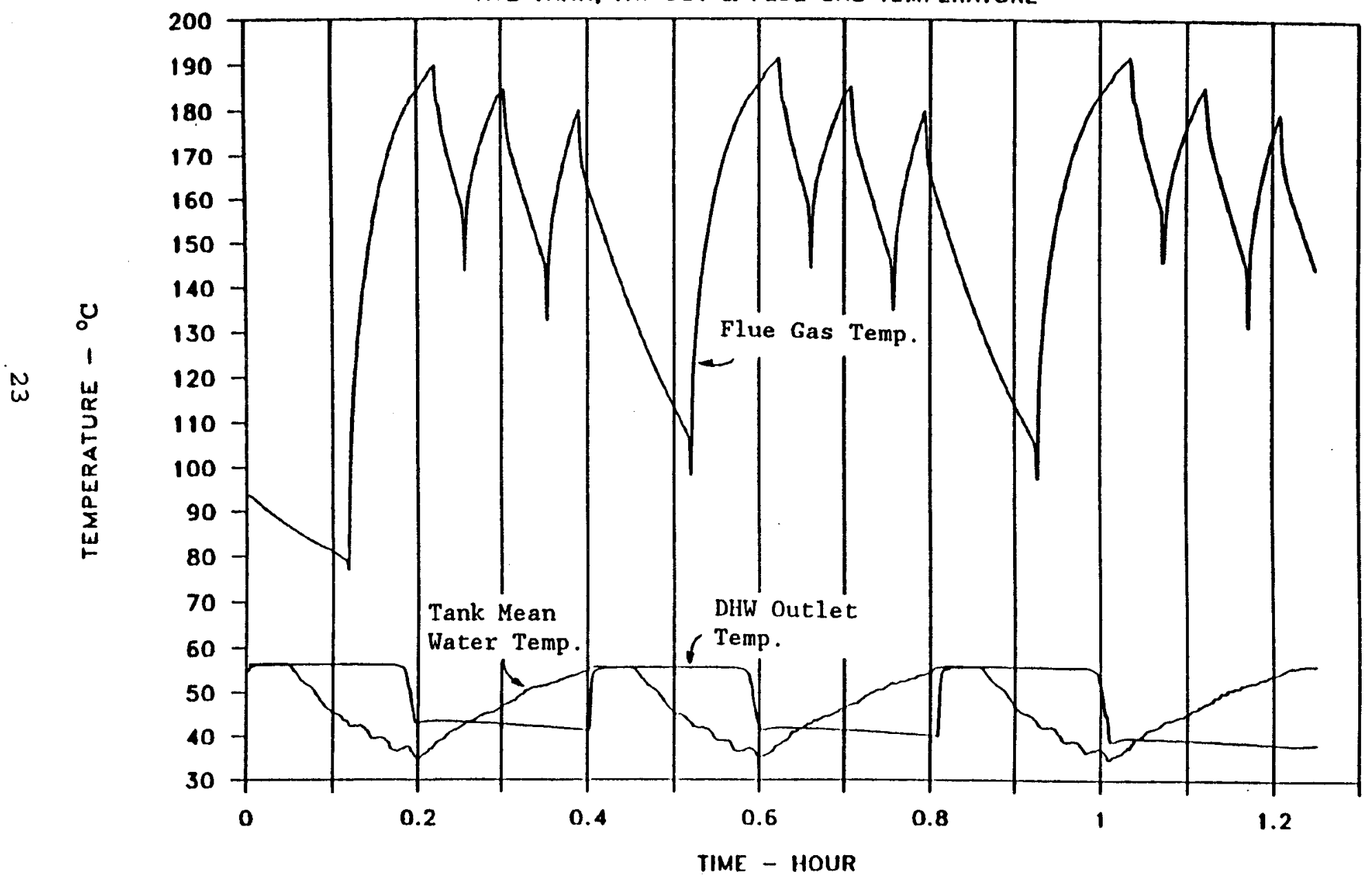

Fig. 7 Flue gas, tank mean water and domestic water outlet temperature during the first hour rating test ( $44 \mathrm{~kW}$ input) 


\section{Type I Integrated Combination Appliance}

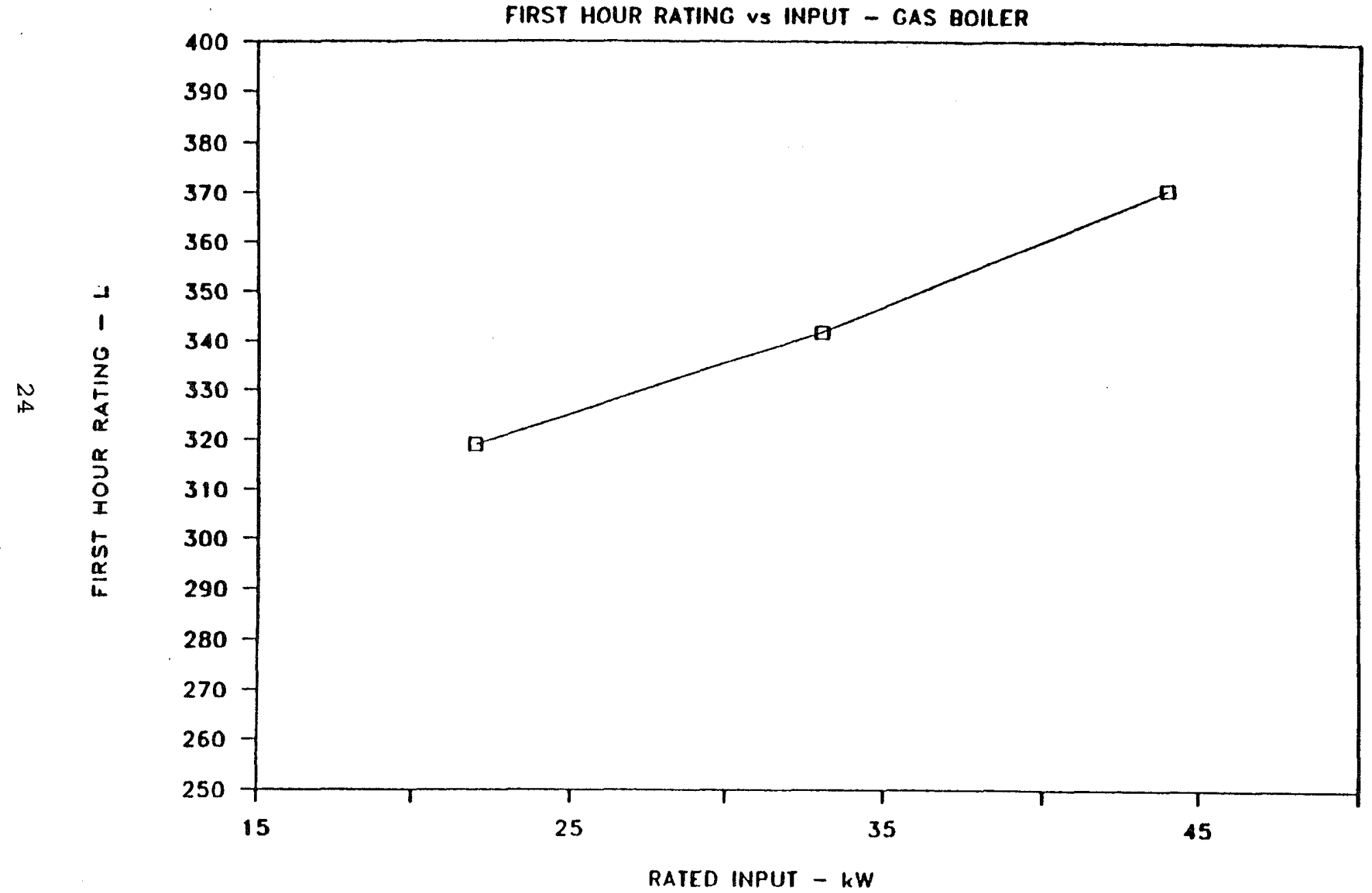

Fig. 8 First hour rating as a function of rated input of a famlly series of boilers with identical storage tank 


\section{Type I Integrated Combination Appliance}

EF,CAE,EFFss,EFFhs vS OIN - GAS BOILER

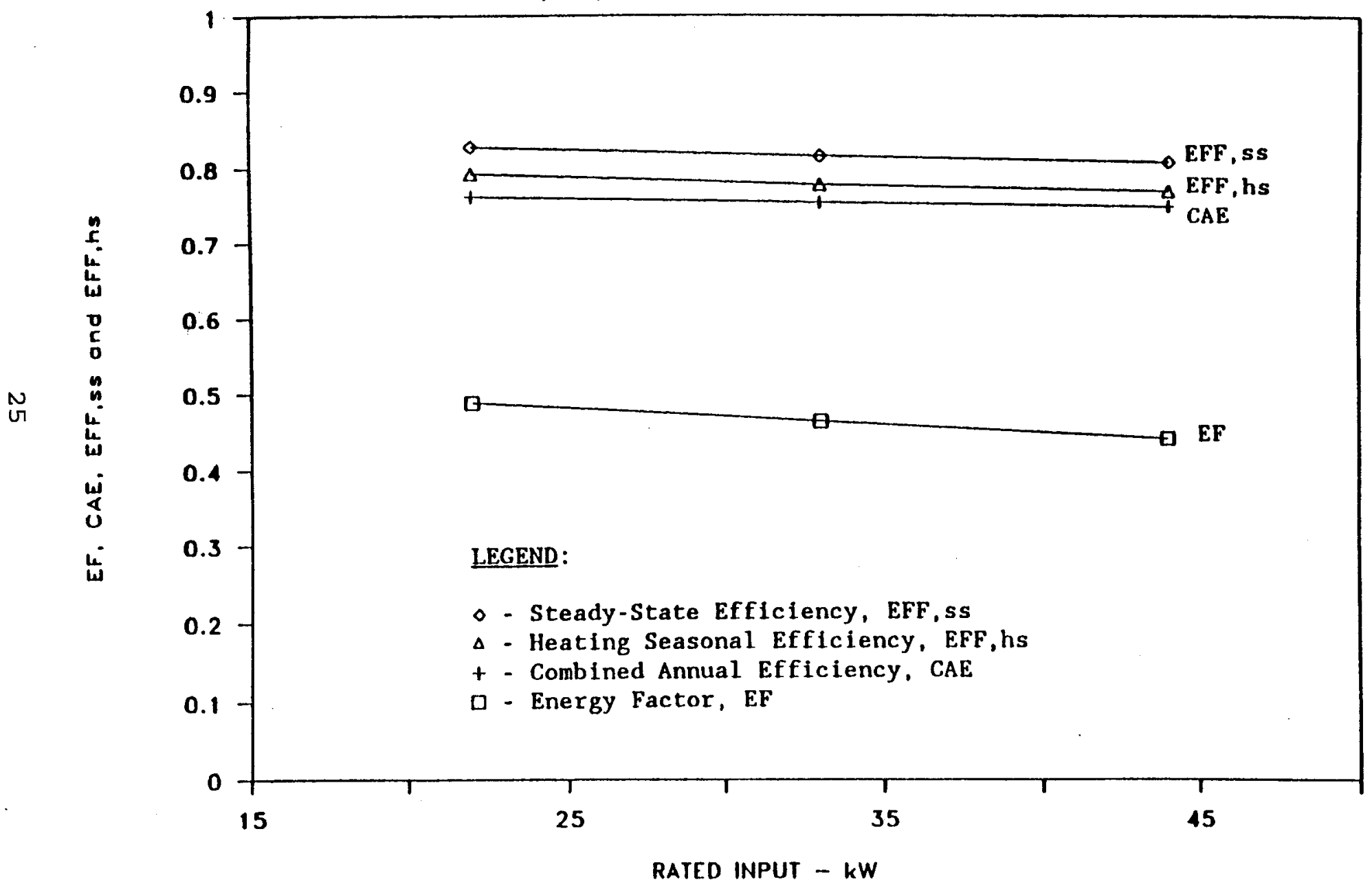

Fig. 9 Energy factor, steady-state efficiency, heating seasonal efficiency and combined annual efflciency (CAE) as a function of rated input of a family series of boilers with Identical storage tank 